\title{
Exploring the Path of Strengthening the Education and Management of Student Party Members in Colleges and Universities in the New Era
}

\begin{abstract}
Yuanshu Gong
School of Marxism, China Jiliang University, Hangzhou 310018, China

*Corresponding author.Email:547382039@qq.com

ABSTRACT

Since the new era, strengthening the education and management of college student party members has played an important role in realizing the all-round development of college student party members, establishing the original mission and improving the quality of college party construction work. Then, we analyze the problems existing in the development of the practical work from three perspectives: student party members in colleges and universities, the content of education and management, and the management team. Finally, this paper proposes the practical paths to cultivate the party spirit and social responsibility of college student party members, enriching the education platform and educational connotation and methods, and strengthening the construction of college student party members management team.
\end{abstract}

Keywords: New Era, Student Party Members in Universities, Education Management, Path.

\section{THE NECESSITY OF}

\section{STRENGTHENING THE EDUCATION}

AND MANAGEMENT OF STUDENT

\section{PARTY MEMBERS IN THE NEW ERA}

The number of college student party members is expanding with the progress of the times. Enhancing the education and management of college student party members in the new era is of vital significance in improving the overall development of college student party members, adhering to the original mission of the party and promoting the improvement of the quality of party building work on campus. Doing a good job in the education and management of college party members in the new era is not only the educational duty of the school, but also an important element in providing excellent reserve strength of party members for the future society, which is directly related to our country's destiny and the bright prospects of the great rejuvenation of the Chinese nation.

\subsection{The Requirement of advancing the Comprehensive Development of Student Party Members in Colleges and Universities}

Strengthening college student party members' education and management in the new era is the requirement of the times to promote the comprehensive development of college student party members. University stage is the key stage of growth and development of college students, and it is also the best period to establish correct outlook on life, values and worldview [1]. College students are the main force of young people and the hope of socialist development, while undergraduate party members are the best in the group of students, and the inexhaustible power for the growth and progress of schools and even the Communist Party of China.

Therefore, the development of college student party members is an indispensable part of the party construction work carried out in colleges and universities. Institutions of higher learning must strengthen the education and management construction of college student party members to ensure the stable development of the student team. When carrying out a series of education and management for college student 
party members, it is essential to cultivate college student party members to internalize Marxist ideology and externalize it, further promote the cultivation of their political quality and firm sense of conviction, and promote the comprehensive improvement of their political theory study and practical exercise ability. In addition, Students need to unify the development of their own country and society, enhance the ideal and belief education to achieve its own full-scale development of themselves. As the youth of the new era, we should enhance the education of ideals and beliefs to achieve the all-round development and open up the great dream of China's continuous progress.

\subsection{The Basic Way to Construct the Original Mission of Student Party Members in Colleges and Universities}

Strengthening the education and management of party members in the new era is the basic way to build the original mission of undergraduate party member. Since the founding of the Communist Party of China, the number of members of the Chinese Communist Party has grown from a few dozens at the beginning to more than 90 million today. Since the founding of the Party one hundred years ago, the Chinese Communist Party has been determined to carry out its mission, and has developed from a "red boat" in Jiaxing South Lake to a "flagship of revival" in China, relying on the continuous practice of the original intention and mission of the Communists, and achieving great achievements through revolution, construction and reform. The Party has made great achievements to win the heartfelt support of the masses.

Maintaining the purity and advancement of the party members is the spiritual pursuit of the communists, and undergraduate party members are an indispensable part of the party membership team. This is conducive to strengthening the party education and party exercise for undergraduate party members, guiding them to establish the cornerstone of belief, replenish the spiritual calcium, steer the ideal sail, and educating them to always maintain the party cultivation of loving, worrying, promoting and protecting the party.

\subsection{An Important Way to Promote the Quality of Party Construction Work in Colleges and Universities}

Strengthening the education and management of student party members in colleges and universities plays the significance role in improving the quality of party building work at school. College student party members education and management is the basic work of party construction work in the school. Political quality and party training possessed by undergraduate party members directly affect whether the grassroots party organizations are carried out smoothly and whether the quality of party construction work in the school is excellent. General Secretary Xi Jinping pointed out in the National Conference on Ideological and Political Work in Colleges and Universities that it is necessary to do a good job in developing party members among teachers and students in colleges and universities, strengthen the education and management of party members, so that every student and teacher party members can love the party, speak the party and work for the party in the party [2]. This important statement has important guiding significance to promote the development of party building work at school.

Therefore, Institutions of higher learning should actively adapt to the changes of the new situation, effectively integrate the current actual situation of the school, closely grasp the college student party member as an indispensable subject. At the same time, Institutions of higher learning need to strengthen the education and management of the group of undergraduate party members in a purposeful and targeted manner, and make every effort to open up a new bright future for the school's party building work. This provides a solid political and ideological guarantee for the development and optimization of higher education institutions.

\section{THE PROBLEMS FACED BY THE EDUCATION AND MANAGEMENT OF STUDENT PARTY MEMBERS IN THE NEW ERA}

The problems facing the college student party members' education and management in the new era are mainly analyzed from three aspects: college student party members, education and management contents and methods, and management team.

\subsection{Diversified Motivation and Low Political Theory Literacy of Student Party Members in Colleges and Universities}

In this era of diversified and fiercely conflicting social thoughts, the consciousness activities of college students have also produced certain conflicts with traditional thoughts, and some complicated problems have gradually emerged.

First of all, many college students who have just entered colleges and universities have high expectations and longing for joining the Communist Party of China. However, it takes a long time from submitting the application to joining the party, the number of students joining the party is very limited and precious, and a comprehensive inspection of party applicants is required.These complicated and cumbersome procedures have deprived a small number of students of the determination to join the Communist Party of China. 
Secondly, some applicants' motives for joining the Party are not correct enough, valuing the red benefits brought by Party membership, considering more the impact of joining the Party on personal interests and personal future development, with obvious utilitarian colors, and lacking the problem of real service consciousness.

Finally, the applicants do not have a comprehensive knowledge of the requirements for joining the Party, the obligations of Party members and the nature, purpose, path and goals of the Party, and they lack political and theoretical knowledge, as well as self-management awareness and management ability.

\subsection{Single Content and Way of Education and Management of Student Party Members in Colleges and Universities}

At present, in the process of education and management of student party members in colleges and universities, many schools still adopt the traditional single classroom teaching method, that is, teachers as the main classroom are responsible for teaching and imparting relevant contents. As the educated, students only receive the knowledge taught by the teacher in this teaching process, without putting forward their own thinking. It is obvious that this education model does not really penetrate the effective communication between educators and educators.

Moreover, a number of schools conduct ideological and political education only for exam-oriented education, and fail to combine it with social practice to train college student party members. The most significant process of ideological and political education is the propagation of the party's line and policy. In the process of education, the ideal effect can not be achieved if only the theory is emphasized, and students can only listen to and understand the lectures passively.

In addition, the activities carried out by student organizations in colleges and universities are colorful and have obvious effects on the growth and success of students, while the activities of college student party branches seem to be the same. in comparison, almost not closely connected with other student organizations, and can not adapt well to the new proposals of the Party and the new problems and new paths faced by student party construction work in the background of the new era.

\subsection{The Professionalism of Student Party Members' Education and Management Team in Colleges and Universities is not Comprehensive Enough}

The education and management of student party members in colleges and universities should be the same as that of other adult party members, which requires highly professional, stable and practical party workers to carry out education and management.

However, through a series of surveys, it can be found that in reality, there are relatively few full-time party teaching staff in colleges, and most of the party work is carried out by university counselors, which also leads to deficiencies and shortcomings in the education and management of student party members in colleges to a certain extent due to the complicated management work of counselors themselves and the need for precise and detailed requirements for the implementation of party-related work [3].

In addition, some colleges also have the real problem of frequent replacement of counselors, because counselors are generally engaged in some party and government-related work, although the new counselors are equally serious and responsible in the work handover, it still takes a lot of time to be familiar with the process of party work. The emergence of this phenomenon also leads to insufficient implementation of party affairs-related work in colleges, and often remains only on the surface, and there are still some optimization problems that need to be solved in active thinking and practical practice.

\section{EXPLORE THE PATH TO STRENGTHEN THE EDUCATION AND MANAGEMENT OF STUDENT PARTY MEMBERS IN COLLEGES AND UNIVERSITIES IN THE NEW ERA}

The problems faced by the college student party members' education and management lead to insufficient play of the role of party members, and the positive aspects of party organizations need to be further improved and perfected. To explore a new journey full of hope and light in this new era, it is necessary to deepen the education and management of college student party members and find their way forward.

\subsection{Strengthen the Cultivation of Party Spirit and Social Responsibility of Student Party Members in Colleges and Universities}

First of all, focus on strengthening the ideal and belief education of college student party members. Ideals and beliefs are the "calcium" of the spirit. The cultivation of college student party members should start with the hot issues of students' concern and combine with their growth reality and development needs, and adopt various ways such as classroom teaching, campus activities and field visits to truly integrate the boring political theory knowledge into the learning life of undergraduate party members, which can help college student party members deeply grasp the connotation of ideals and beliefs education and 
maximize the effectiveness of learning and beliefs education. It will help the student party members of colleges and universities to establish their lofty aspirations and ambitious goals and contribute their youthful power to the modernization of the motherland.

Secondly, it is necessary to enhance and cultivate the patriotism and social responsibility consciousness of undergraduate student party members. According to the essence of the spirit of voluntary service of the Communist Party of China, colleges and universities should combine the actual work of grass-roots party building with the education and management mode of integrating students' campus activities with social practice activities, such as carrying out grass-roots legal aid organizations or volunteer activities, etc., to cultivate the values of courageous practice and dedication of undergraduate party members and enhance the social responsibility consciousness of college student party members. Meanwhile, we continue to carry out party building activities in the form of party activity days and party day activities, which enriches the educational connotation and educational effect.

Finally, we have to focus our attention on cultivating the power of role models in the education of undergraduate party members, actively encouraging college student party members to be good role models in politics, study and life, shaping the advanced image of party members, establishing the concept that a party member is a banner, making full use of the advanced models of university student party members to guide the surrounding students to actively approach the party organization and build a harmonious atmosphere for the pursuit of excellence [4].

\subsection{Strengthen the Expansion of Educational Platforms and Enrich the Contents and Methods of Education}

It is essential to break through the traditional single theoretical teaching mode in the process of party education for undergraduate party members, and take a "close" approach to students in colleges and universities and adopt a multi-style education approach that is wellreceived.

First of all, the main education platform for the education and management of undergraduate party members is in the classroom, but the innovative expansion of the education platform needs to be established in the two positions of dormitories and clubs, so as to open the last kilometer of party building work [5]. In addition to classroom education, it is also indispensable to play a vital role in the daily life of college students to ensure that the party organization and party work are fully covered at all times and in all places. The dormitory is a momentous place for college students to live and exchange ideas in the school, and student associations have gradually become a new position for ideological education. Institutions of higher learning ought to actively explore the work of establishing temporary party branches in student dormitories or student unions to heighten the enthusiasm and sense of belonging of party members. Only in this way can the party's vanguard role be effectively brought into play.

Secondly, using network media to expand network application ability is a new means and way. Internet information keeps progressing with the development of the times, new network media are popular and widely used among college students, and gradually become a key component of college students' study and life. In response to this situation, party construction workers in colleges are supposed to make full use of new media platforms such as "Learning Power" to make college student party members receive education and training anytime and anywhere, and integrate online and offline organically. In addition, they can also make full use of the online platform of school micro-signal to release the related party building theme content, so as to stimulate students to improve their good reading skills and have an effect on enhancing the party cultivation and spiritual construction of college student party members.

Finally, strengthening extra-curricular practical activities can enrich the practical ability of college student party members' education. Institutions of higher learning ought to execute colorful and special teaching activities through other activities such as knowledge competitions and reading exchanges as carriers, so as to boost the attraction of undergraduate party members to party building education. Colleges and universities can also actively build social practice bases of the party, vigorously organize college students to revisit the revolutionary road of the old generation or carry out voluntary service activities to improve all aspects of quality and practical ability of undergraduate party members, further enrich the content of party building.

\subsection{Strengthen the Construction of Student Party Management Team in Colleges and Universities}

For the sake of effectively boost the professional quality, working competence, ideological and political quality and professional spirit of undergraduate party members education and management team, the school and relevant departments should educate and train the college party construction workers accordingly to form a undergraduate party members education and management team with professional party construction work ability [6].

First of all, we are supposed to concentrate our attention on planning the training methods of student party workers in colleges, and divide the party building 
organization workers into full-time and part-time to carry out professional training respectively. The fulltime party building organization workers are fully responsible for the party building work of the grassroots party committees in colleges, while the part-time party building organization workers assist the leading cadres to do a good job in the education and management of undergraduate party members, so that the education and management of undergraduate party members can be performed smoothly in an orderly manner. In terms of training methods, we concentrate on more development and exploration of educational and research resources of party history and party construction in colleges and universities as well as the national red education bases for professional training, so as to build a systematic and scientific curriculum training environment for the management of student party members in colleges, which is conducive to the rapid development and continuous progress of party building work.

Secondly, colleges and universities can also establish corresponding assessment mechanisms or incentive mechanisms, open up development channels, fully arouse the enthusiasm and initiative of college student management teams, and give recognition and development space to party building workers.

Once again, when choosing party construction workers, we can choose party teachers with excellent work and party cultivation, who have advanced party ideology and cultural knowledge and can full activate their functional characteristics and the role of party teachers to provide students with excellent educational ideas.

Finally, institutions of higher learning are supposed to actively encourage and recommend outstanding graduate students with academic qualities to take part in the party education and management of college students, and a professional and comprehensive party building group for undergraduates can be established, and a number of excellent undergraduates can truly participate in their own education and management process independently.

\section{CONCLUSIONS}

Reinforcing the education and management of college student party members in the new era is of vital significance in improving the overall development of college student party members, adhering to the original mission of the party and promoting the improvement of the quality of party building work on campus. However, in the face of various challenges in the process of work, institutions of higher learning are supposed to continue to actively explore the practical path to strengthen the education and management of undergraduate party members in a new environment, cultivate the party cultivation and social responsibility of undergraduate party members, enrich the education platform and education connotation and methods, strengthen the construction of undergraduate party member management team, grasp the direction of the growth of undergraduate party member education and management, and cultivate undergraduate party members to become qualified successors of China's socialist construction.

\section{REFERENCES}

[1] Shen Zilong, Dang Chao, Effective ways to do a good job of education and management of college students in the new era (J), Employment and Security,2021, pp.142-143. (In Chinese)

[2] Xi Jinping stressed at the national conference on ideological and political work in colleges and universities: the ideological and political work throughout the whole process of education and teaching to create a new situation in the development of China's higher education (J), Practice (Ideological and theoretical version). 2017, pp. 30-31. (In Chinese)

[3] Chi Haoting, Research on the necessity of strengthening the education of young students' party members in colleges and universities in the new era $(\mathrm{J})$,Science and Education Literary Exchange (Upper Edition),2019, pp. 26-27. (In Chinese)

[4] Han Jian, Du Dejian, Wang Ning, The current situation of the vanguard role of college students in the new era and the path to enhance it $(\mathrm{J})$,Beijing Education(Moral Education),2020, pp. 12-14. (In Chinese)

[5] Liu Deqiang, Jiang Zhenzhen, Research on the longterm mechanism of strengthening the education and management of college students' party members in the new era $(\mathbf{J})$, Shanghai Party History and Party Construction,2020, pp. 58-61.(In Chinese)

[6] Tang Fen, Exploring the path of strengthening the daily education and management of college students in the new era $(\mathrm{J})$, Science and Education Literary Exchange (Midterm), 2020, pp. 31-33. (In Chinese) 